\title{
Common toxidromes in movement disorder neurology
}

\author{
N Malek, ${ }^{1}$ M R Baker ${ }^{2,3,4}$
}

'Department of Neurology, Ipswich Hospital NHS Trust, Ipswich, UK

${ }^{2}$ Department of Neurology, Royal Victoria Infirmary, Newcastle-upon-Tyne, UK ${ }^{3}$ Department of Clinical Neurophysiology, Royal Victoria Infirmary, Newcastle -uponTyne, UK

${ }^{4}$ Institute of Neuroscience, The Medical School, Newcastle University, Newcastle-uponTyne, UK

Correspondence to Dr Naveed Malek, Ipswich Hospital NHS Trust, Ipswich IP4 5PD, UK; nmalek@nhs.net

Received 28 May 2016 Revised 13 September 2016 Accepted 14 September 2016 Published Online First

7 October 2016
CrossMark

To cite: Malek N, Baker MR. Postgrad Med J 2017;93:326-332.

\begin{abstract}
Background Physicians can come across patients who are exposed to certain prescription drugs or toxins that can result in adverse effects and complications which have high rates of morbidity and mortality.

Objective To summarise the key clinical features and management of the common movement disorder toxidromes relevant to physicians (with an interest in neurology).
\end{abstract}

Methods We searched PUBMED from 1946 to 2016 for papers relating to movement toxidromes and their treatment. The findings from those studies were then summarised and are presented here.

Results The key features of 6 of the common movement disorder toxidromes and their treatment are tabulated and highlighted. The management of toxidromes with the highest mortality like neuroleptic malignant syndrome and serotonin syndrome are discussed in detail.

Conclusion There are several toxidromes that have the potential to become a serious life-threatening emergency if there is a delay in recognition of key clinical features and instituting the appropriate treatment at the earliest is crucial.

\section{INTRODUCTION}

A toxidrome or toxic syndrome can be defined as a constellation of findings that are evident either from the physical examination of the patient or from ancillary testing, which may result from drug overdose, or withdrawal or exposure to a toxin. ${ }^{1}$ Understanding of the pathophysiology of these disorders along with a high index of suspicion in the relevant clinical context is the key to recognition, for example, a patient with high fever and rigidity on antipsychotics with dopamine receptor blocking potential could be suffering from a neuroleptic malignant syndrome (NMS) while a patient with myasthenia gravis on an anticholinesterase medication such as pyridostigmine with excess salivation or perspiration can be recognised by the clinician to be experiencing a cholinergic toxidrome.

This article is focused on a discussion of toxidromes relevant to general neurology and a more detailed discussion of toxidromes resulting from chemical and animal neurotoxins relevant to emergency medicine practice is beyond the scope of this article and the reader is referred elsewhere for a comprehensive account. Neurological emergencies that have at their heart an underlying toxidrome are elaborated here along with the appropriate clinical context. The description that follows is that of single agent toxidromes and multiagent toxidromes can show a combination of signs and symptoms or additional problems but are not described here $^{12}$ (table 1$)$.

\section{Anticholinergic toxidrome}

Central anticholinergics such a trihexyphenidyl have traditionally been used in the treatment of Parkinson's disease ${ }^{8}$ though with the advent of dopaminergic therapies ${ }^{9}$ and the cognitive side effects of anticholinergics ${ }^{10}$ their use is now declining. Other uses have include generalised dystonia, ${ }^{11}$ rhythmic-oscillatory movements of brainstemcerebellar origin (palatal myoclonus, pendular nystagmus, facial myokymia) ${ }^{12}$ and various types of tremor including rubral tremor. ${ }^{13}$ Antipsychotics, tricyclic antidepressants and many first-generation antihistamines also have prominent anticholinergic activity. The salient features of an anticholinergic toxidrome are described in table 1 and its differentiation from a cholinergic toxidrome in table 2 . Additional features that may be seen include restlessness, visual hallucinations, dysarthric speech, mydriasis, urinary retention, fever, tachycardia and red, dry skin. ${ }^{14}$

Central anticholinergic syndrome (CAS) is not often considered in the differential diagnosis of delirium but should strongly be suspected in patients with a recent history of anticholinergic medication administration as morbidity is high. Moreover, CAS can occur even after only a single dose of an anticholinergic agent, as an idiosyncratic phenomenon. ${ }^{3}$

\section{Drug-induced parkinsonism}

Drug-induced parkinsonism (DIP) is the second most common cause of an akinetic rigid syndrome in the Western world and its prevalence is increasing due to the rise of polypharmacy. DIP was initially reported as a complication of neuroleptic medication use in psychiatric patients, but it can also be caused by several other classes of drugs including antiemetics, antidepressants, calcium channel antagonists, antiarrhythmics and antiepileptics. Although traditionally considered to be a completely reversible condition, DIP may persist long after drug withdrawal. At least $10 \%$ of patients with DIP develop persistent and progressive parkinsonism in spite of the discontinuation of the offending agent that represents unmasking of a preclinical neuronal dopaminergic deficit. The best treatment of DIP therefore is caution when prescribing drugs with a potential to cause this problem carefully weighing benefits and risks of such a prescription particularly for psychiatric patients when their state of mind does not allow them to make a rational decision based on information provided; nevertheless there will be a case 
Table 1 Salient features of the toxidromes relevant to neurology practice

\begin{tabular}{|c|c|}
\hline Toxidrome & Salient features \\
\hline Adrenergic toxidrome & Agitation, confusion, tachycardia, hypertension, dilated pupils, paranoid psychosis \\
\hline Anticholinergic toxidrome & Confusion, dry flushed skin and mucous membranes, fever, mydriasis, sluggish bowel movements, urinary retention ${ }^{3}$ \\
\hline Benzodiazepine toxidrome & Depressed consciousness*, impaired motor coordination, slurred speech, blurry vision, erratic behaviour, respiratory depression ${ }^{2}$ \\
\hline Cholinergic toxidrome & $\begin{array}{l}\text { Diaphoresis, hypersalivation, fasciculation, lacrimation, miosis, increased frequency of bladder and bowel movements, decreased } \\
\text { consciousness or agitation, acute respiratory failure }{ }^{4}\end{array}$ \\
\hline Drug-induced parkinsonism & Tremor, bradykinesia and rigidity that is usually symmetrical but can be asymmetrical \\
\hline Neuroleptic malignant syndrome & $\begin{array}{l}\text { Altered mental status ranging from agitation to coma, fever, rigidity, bradykinesia, tremor, high creatine kinase ( } \uparrow C K) \text {, autonomic } \\
\text { hyperactivity and respiratory depression }\end{array}$ \\
\hline Parkinson hyperpyrexia syndrome & Clinical features are identical to the neuroleptic malignant syndrome \\
\hline Opioid toxidrome & Depressed consciousness* ${ }^{*}$ respiratory depression, miosis, sluggish bowel movements or constipation ${ }^{5}$ \\
\hline Serotonin syndrome & Agitation, bradykinesia, fever, rigidity, hyper-reflexia, autonomic hyperactivity, increased bowel movements, confusion ${ }^{6}$ \\
\hline $\begin{array}{l}\text { Tardive (antidopaminergic) } \\
\text { syndromes }\end{array}$ & Various phenotypes of tardive syndromes can exist singly or in combination \\
\hline a. Tardive dyskinesia & Choreiform movements-oral, buccal and lingual \\
\hline b. Tardive dystonia & Focal dystonia > segmental dystonia> generalised dystonia \\
\hline c. Tardive tremor & Postural and kinetic that persist despite DRBA withdrawal \\
\hline d. Tardive myoclonus & Myoclonic jerks in isolation or combination with tardive dystonia or akathisia \\
\hline e. Tardive akathisia & Inner and manifest restlessness \\
\hline f. Tardive complex & Three or more tardive movement disorders in the same patient \\
\hline $\begin{array}{l}\text { Tricyclic antidepressant } \\
\text { toxidrome }\end{array}$ & $\begin{array}{l}\text { Dry mouth, blurred vision, dilated pupils, sinus tachycardia, pyramidal neurological signs, and depressed consciousness, convulsions, } \\
\text { respiratory depression, hypotension and prolongation of the PR and QT intervals }{ }^{7}\end{array}$ \\
\hline
\end{tabular}

Table 2 Clinical differentiating features between cholinergic and anticholinergic toxidromes ${ }^{15}$

\begin{tabular}{|c|c|c|}
\hline Characteristics & Cholinergic toxidrome & $\begin{array}{l}\text { Anticholinergic } \\
\text { toxidrome }\end{array}$ \\
\hline Pupils & Constricted & Dilated \\
\hline Temperature & Normal & Hyperthermia \\
\hline Heart rate & Bradycardia & Tachycardia \\
\hline Skin & Increased perspiration & Dry skin \\
\hline $\begin{array}{l}\text { Mucous } \\
\text { membranes }\end{array}$ & $\begin{array}{l}\text { Sialorrhoea, rhinorrhea, } \\
\text { lacrimation, bronchorrhea }\end{array}$ & Dry secretions \\
\hline Bladder & Urinary frequency & Urinary retention \\
\hline Bowel & Increased peristalsis & Constipation \\
\hline
\end{tabular}

where such medications will be required by the patient's clinical condition but the doses should be kept at the lowest possible required. ${ }^{16}$

\section{Neuroleptic malignant syndrome}

This toxidrome is mainly characterised by hyperthermia, altered mental state, haemodynamic dysregulation, elevated serum creatine kinase and rigours. It has been associated with multisystem organ failure potentially leading to rhabdomyolysis, acute respiratory distress syndrome and disseminated intravascular coagulation. ${ }^{17}$ It can be associated with exposure to dopamine receptor blocking agents (DRBAs) (table 3) and also with the sudden withdrawal of dopamine agonists when it is referred to as neuroleptic malignant-like syndrome or the parkinson hyperpyrexia syndrome (PHS).

An international consensus study of NMS has proposed diagnostic criteria reflecting a broad consensus among an international multispecialty panel of physicians (table 4$).^{18}$

Permanent neurological injury may occur if there is a delay in recognition or treatment.
Table 3 Drugs associated with the neuroleptic malignant syndrome

\begin{tabular}{ll}
\hline Class & Drugs \\
\hline $\begin{array}{l}\text { Typical } \\
\text { antipsychotics }\end{array}$ & $\begin{array}{l}\text { Chlorpromazine, droperidol, fluphenazine, haloperidol, } \\
\text { mesoridazine, molindone, loxapine, perphenazine, } \\
\text { pimozide, thiothixene, trifluoperazine, thioridazine }\end{array}$ \\
$\begin{array}{l}\text { Atypical } \\
\text { antipsychotics }\end{array}$ & $\begin{array}{l}\text { Clozapine, olanzapine, risperidone, quetiapine, } \\
\text { Zthers }\end{array}$ \\
\hline
\end{tabular}

The differential diagnosis includes heatstroke, idiopathic malignant catatonia, malignant hyperthermia with inhalational anaesthetics such as halothane, CAS and serotonin syndrome (SS).

Neuroleptic-induced catatonia and mild forms of NMS share parkinsonian features, catatonic symptoms and low grade fever, and have been described in patients receiving antipsychotic agents. Some consider the overlapping features as a continuum on a 'neuroleptic toxicity spectrum'. ${ }^{19}$ Woodbury and Woodbury ${ }^{20}$ describe five stages in this spectrum from an 'extrapyramidal reaction' (Stage 1) to severe NMS (Stage 5) (table 5).

\section{Parkinson hyperpyrexia syndrome}

PHS in the past has been referred to with its alternative name acute dopamine depletion syndrome. ${ }^{21}$ Fatal hyperpyrexia with a severe akinetic rigid syndrome can occur following acute levodopa withdrawal. The clinical features are the same as those of NMS, and this can include any combination of fever, parkinsonian rigidity, confusion and raised creatine kinase; the distinction being that no neuroleptic is involved. The rapid decrease in dopaminergic activity may be important in causing the syndrome, therefore, if dopaminergic medications require withdrawal this should be achieved gradually rather than suddenly. ${ }^{22}$ 
Table 4 Diagnostic criteria for neuroleptic malignant syndrome according to an international consensus study. ${ }^{18}$

\begin{tabular}{ll}
\hline Criteria & Findings \\
\hline Essential criteria & $\begin{array}{l}\text { Exposure to dopamine antagonist or dopamine agonist } \\
\text { withdrawal in past } 72 \text { hours }\end{array}$ \\
Clinical features & $\begin{array}{l}\text { Hyperthermia, }>100.4^{\circ} \mathrm{F} \text { or }>38.0^{\circ} \mathrm{C} \text { on at least two } \\
\text { occasions } \\
\text { BP elevation } \geq 25 \% \text { above baseline } \\
\text { BP fluctuation } \geq 20 \mathrm{~mm} \mathrm{Hg} \text { (diastolic) or } \geq 25 \mathrm{~mm} \mathrm{Hg} \\
\text { (systolic) change within } 24 \text { hours } \\
\text { HR } \geq 25 \% \text { above baseline }\end{array}$ \\
& RR $\geq 50 \%$ above baseline \\
Laboratory & CK $>4 \times$ normal \\
features & Other central nervous system, systemic and toxic causes of \\
Exclusion & hyperthermia \\
criteria &
\end{tabular}

Additional features can include generalised stimulus-sensitive myoclonus and myoglobinuric renal failure. ${ }^{23} 24$

Although withdrawal of levodopa is the most common cause of PHS, sudden withdrawal of other agents, including amantadine, dopamine agonists and catechol-O-methyltransferase inhibitors can also cause this syndrome. Patients with Parkinson's disease are susceptible to PHS due to its inherent dopaminedepleted state, but PHS has also been reported in patients with atypical parkinsonism, for example multiple system atrophy and progressive supranuclear palsy. ${ }^{25} 26$

\section{Serotonin syndrome}

SS is an iatrogenic condition caused by exposure to drugs that have effects on serotonergic transmission in the brain. It was first recognised in the 1960s in depressed patients exposed to monoamine oxidase inhibitors (MAOIs). ${ }^{27}$ This syndrome has also been referred to in the literature as the serotonin behavioural or hyperactivity syndrome. Although initial reports concerned patient exposure to either MAOI or selective serotonin reuptake inhibitors (SSRIs), exposure specifically to these classes of drugs is not required for this syndrome to develop and several other drugs can also cause this syndrome (table 6). The development of the SS is unpredictable as it can develop at therapeutic doses but co-prescription of these two drug classes is a contraindication. The salient features are described in table 1 and although it is
Table 6 Drugs associated with the serotonin syndrome $\begin{array}{llll}6 & 28 & 30\end{array}$

\begin{tabular}{|c|c|}
\hline Class & Drugs \\
\hline SSRI & $\begin{array}{l}\text { Citalopram, escitalopram, fluoxetine, fluvoxamine, } \\
\text { paroxetine, sertraline }\end{array}$ \\
\hline SNRI & Venlafaxine \\
\hline $\begin{array}{l}\text { Serotonin receptor } \\
\text { antagonist }\end{array}$ & Trazodone \\
\hline Amphetamines & $\begin{array}{l}\text { 3,4-methylenedioxymethamphetamine (Ecstasy), } \\
\text { dextroamphetamine, methamphetamine, sibutramine }\end{array}$ \\
\hline MAOI & Phenelzine, moclobemide* \\
\hline Opioids & Meperidine (pethidine), fentanyl, tramadol \\
\hline Others & Lithium, sodium valproate, \\
\hline
\end{tabular}

often described as a clinical triad of mental-status changes, autonomic hyperactivity and neuromuscular abnormalities, not all of these findings are consistently present in all patients with the disorder. ${ }^{28}$ Additional problems include seizures, QT prolongation, arrhythmias and the syndrome of inappropriate antidiuretic hormone secretion. ${ }^{29}$

Two different sets of criteria have been proposed for the recognition of SS in clinical settings (figure 1, table 7).

The clinical differentiation of SS from NMS is crucial as treatments are different. There are some physical signs that can help in making this distinction (bold type in table 8), thereby aiding treatment decisions.

\section{Tardive syndromes}

As opposed to acute toxidromes, chronic exposure to DRBAs can cause a variety of movement disorders that develop gradually although acute toxicity can also occur in the form of sudden dystonic reactions and oculogyric crises. ${ }^{33}$ The various phenotypes of dopamine receptor blockade related tardive syndromes are described in table 1.

Other tardive complications that have been reported include tardive dystonia of the pharynx causing dysphagia ${ }^{34}$ and respiratory irregularities with audible involuntary respiratory noises that may be accompanied by prominent gasping and episodes of aspiration pneumonia. ${ }^{35}$

Table 5 Stages of 'neuroleptic induced toxicity spectrum'20

\begin{tabular}{|c|c|c|c|}
\hline Stages & Muscle rigidity & Autonomic instability & Temperature \\
\hline $\begin{array}{l}\text { Stage } 1 \\
\text { (EPR) }\end{array}$ & Mild-moderate & Nil & Normal \\
\hline $\begin{array}{l}\text { Stage } 2 \\
\text { (NIC) }\end{array}$ & $\begin{array}{l}\text { Mild-moderate + } \\
\text { cog-wheel rigidity }\end{array}$ & $\begin{array}{l}\text { HR: } 70-90 \\
\text { RR: } 18-28 \\
\text { BP: } 120 / 70-140 / 80 \mathrm{~mm} \mathrm{Hg}\end{array}$ & Normal \\
\hline $\begin{array}{l}\text { Stage } 3 \\
\text { (Mild NMS) }\end{array}$ & $\begin{array}{l}\text { Mild-moderate }+ \\
\text { cog-wheel rigidity }\end{array}$ & $\begin{array}{l}\text { HR: } 90-110 \\
\text { RR: } 25-30 \\
\text { BP: } 130 / 80-150 / 90 \mathrm{~mm} \mathrm{Hg}\end{array}$ & $38-39^{\circ} \mathrm{C}$ \\
\hline $\begin{array}{l}\text { Stage } 4 \\
\text { (Moderate NMS) }\end{array}$ & $\begin{array}{l}\text { Moderate-severe+ } \\
\text { lead-pipe rigidity }\end{array}$ & $\begin{array}{l}\text { HR: } 110-130 \\
\text { RR: } 25-30 \\
\text { BP: } 140 / 100-210 / 110 \mathrm{~m} \mathrm{Hg}\end{array}$ & $39-40^{\circ} \mathrm{C}$ \\
\hline $\begin{array}{l}\text { Stage } 5 \\
\text { (Severe NMS) }\end{array}$ & Severe lead-pipe rigidity & $\begin{array}{l}\text { HR: } 130-150 \\
\text { RR: } 30-36 \\
\text { BP: } 140 / 100-210 / 110 \mathrm{~m} \mathrm{Hg}\end{array}$ & $39-42^{\circ} \mathrm{C}$ \\
\hline
\end{tabular}

BP, blood pressure; EPR, extrapyramidal reaction; HR, heart rate; NIC, neuroleptic-induced catatonia; NMS, neuroleptic malignant syndrome; RR, respiratory rate. 
Figure 1 Hunter serotonin toxicity criteria proposed by Dunkley (adapted from Dunkley et al [32]).

Is there a history of exposure to serotonergic drugs?

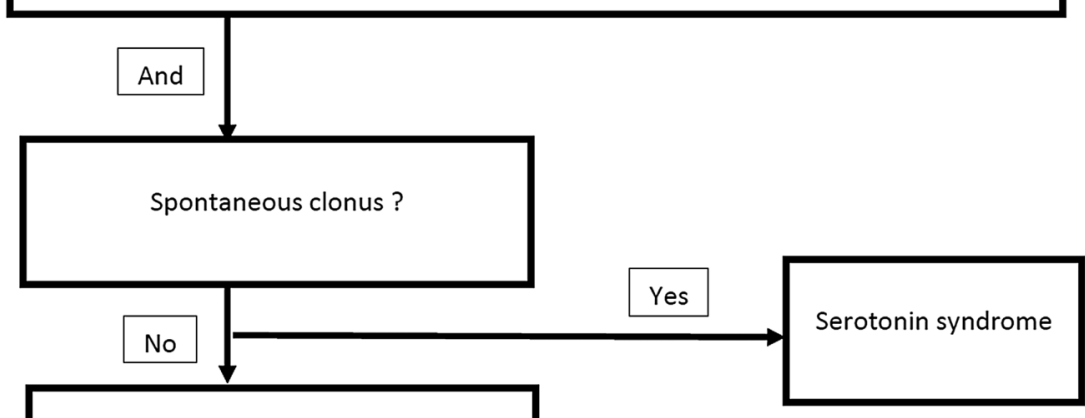

Inducible clonus with agitation and diaphoresis?

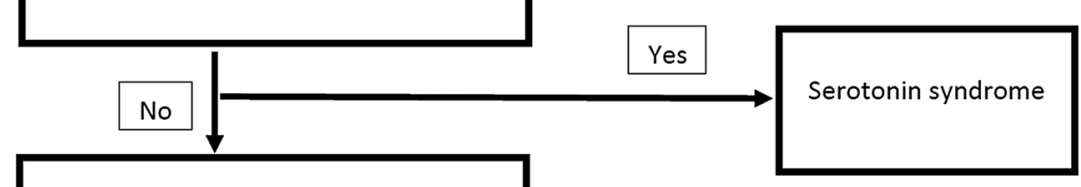

Ocular clonus with agitation and diaphoresis?

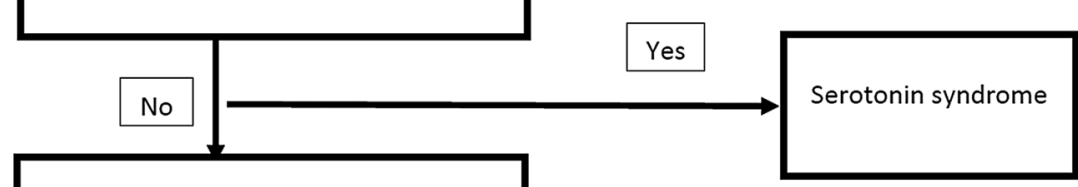

Tremor and hyper-reflexia?

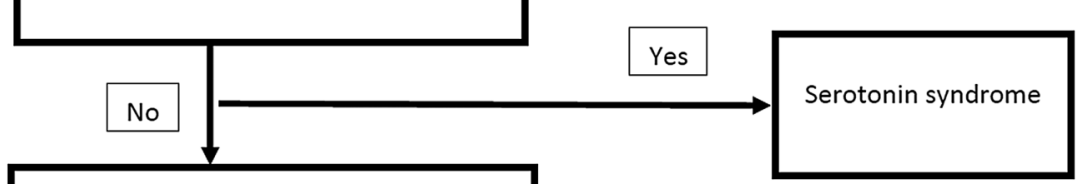

Hypertonia, pyrexia (temp $>38^{\circ} \mathrm{C}$ ) and ocular or inducible clonus?

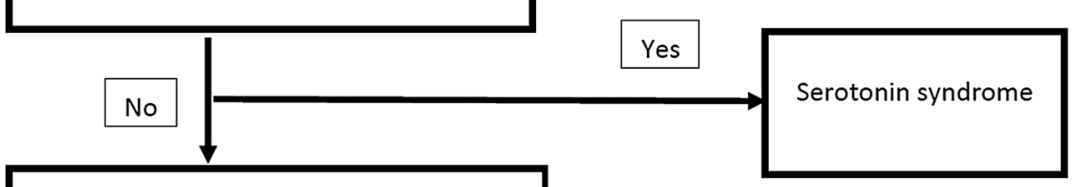

No serotonin syndrome

\section{EVALUATION}

History

A carefully obtained history from the patient is crucial to correctly identifying the toxidrome under consideration. However, under certain circumstances, such as when dealing with a comatose patient who has taken an overdose of SSRIs where the depressed level of consciousness is a manifestation of the toxidrome, getting a first-hand account may not be possible but information gleaned from attendants, carers and family members about medications, comorbidities and exposure to toxins can lead the clinician to the correct diagnosis. Recording the chronology of events, the tempo of development of clinical features and a detailed medication history are first steps in hypothesis generation by the clinician which can be further confirmed by a methodical clinical examination.
A distinction between acute toxidromes such as NMS from exposure to dopamine receptor blockers from chronic tardive syndromes such as tardive chorea arising from exposure to the same class of drugs is as much historical as it is based on clinical examination findings.

\section{Examination}

A general physical examination assessing for vital signs including temperature, skin, mucous membranes, and cardiovascular examination and abdominal examination may help provide clues. For example, a patient with fever, dry mucous membranes, tachycardia and sluggish bowel sounds on auscultation could point towards a diagnosis of an anticholinergic toxidrome if substantiated by a history of prescription of drugs with anticholinergic side effects. 


\begin{tabular}{ll} 
Table 7 & Sternbach's criteria for diagnosis of serotonin syndrome \\
\hline 1. & Recent addition or increase in a known serotonergic agent \\
2. & Absence of other possible aetiologies (infections, substance abuse) \\
3. & No recent addition or increase of a neuroleptic agent \\
4. & At least three of the following symptoms: \\
& Mental status changes (confusion, hypomania) \\
& Agitation \\
& Myoclonus \\
& Hyper-reflexia \\
& Diaphoresis \\
& Shivering \\
& Tremor \\
& Diarrhoea \\
& Incoordination \\
& Fever
\end{tabular}

Table 8 Differentiating features between neuroleptic malignant syndrome (NMS) and serotonin syndrome (SS) ${ }^{27} 29$

\begin{tabular}{|c|c|c|}
\hline Characteristics & NMS & SS \\
\hline Precipitant & $\begin{array}{l}\text { Dopamine } \\
\text { antagonist }\end{array}$ & Serotonergic drugs \\
\hline Temperature & $\begin{array}{l}\text { Febrile, tachycardic, } \\
\text { flushed }\end{array}$ & Febrile, tachycardic, flushed \\
\hline Mental status & $\begin{array}{l}\text { Depressed } \\
\text { consciousness* }\end{array}$ & $\begin{array}{l}\text { Depressed consciousness* or } \\
\text { agitated confusion }\end{array}$ \\
\hline Eye signs & Normal pupils & Dilated pupils, ocular clonus \\
\hline Parkinsonism & Tremor, rigidity & Tremor, rigidity \\
\hline UMN signs & Normal reflexes & $\begin{array}{l}\text { Hyper-reflexia, clonus, } \\
\text { extensor plantar responses }\end{array}$ \\
\hline $\begin{array}{l}\text { Gastrointestinal } \\
\text { symptoms }\end{array}$ & Normal & Diarrhoea \\
\hline
\end{tabular}

A focused neurological examination for the most part compliments the findings of a general physical examination and must be directed to look at pupillary responses, fundi, tone, deep tendon reflexes and gait if the patients is mobile but in most cases of significant overdose the patient's state of alertness, cognition and behaviour may not allow a detailed examination where cooperation is desired. Eliciting upper motor neuron signs in a febrile, rigid comatose patient may be crucial in distinguishing NMS from SS (table 8) when a full drug history is not accessible.

\section{DIAGNOSTIC TESTS}

Many of the clinical features described above such as mydriasis, fever, rigidity even when they are part of a constellation can be due to several medications or toxins and therefore confirmatory tests are sometimes required. For example, an awake and alert patient who presents with torticollis after an injection of metoclopramide, a dopamine receptor antagonist, can be easily recognised as an iatrogenic drug reaction. Blood and urine drug testing may be helpful in certain circumstances positively identifying the culprit drug and helping to start definitive treatment where one is available or required. However, the drawbacks of waiting for the availability of test results from a referral centre, false positives and false negatives can lead to delays in instituting treatment. Life-saving and emergency treatments in such a scenario can be empirical and necessary but clinical judgement in analysing historical data and examination findings can guide the clinician to the correct course of action.

Reaching the correct diagnosis early is essential to the successful management of a life-threatening toxidrome. That NMS can be misdiagnosed as SS illustrates the perils of making an incorrect diagnosis as the management is very different.

\section{MANAGEMENT}

The Airway, Breathing, Circulation, Disability, Exposure (ABCDE) approach is applicable in all clinical emergencies for immediate assessment and treatment. ${ }^{36}$ Once the first three components (airway, breathing and circulation) have been assessed and secured, standard treatment follows to stabilise the deranged physiological parameters in order to preserve life and prevent harm. Not all the treatment recommendations provided here are based on evidence obtained from high quality clinical trials; where such evidence is lacking clinical judgement and consensus opinion among physicians is the next best option in what can be unchartered territory.

General measures for all the toxidromes discussed include withdrawal of the offending agent and providing supportive care which may include rehydration with intravenous fluids, cooling measures if patients are febrile and instituting corrective measures to stabilise vital signs such as low blood pressure. Specific therapy however will depend on the correct identification of the underlying toxidrome, for example, dopamine agonists can be used for the treatment of NMS but can exacerbate the problems in someone with SS. Herein lies the importance of using clinical acumen and the power of observation to differentiate between syndromes that may bear a superficial resemblance to one another. The intensity of therapy in general will depend on the severity of illness. A treatment outline of several toxidromes is shown in table 9 and a more detailed description of the potentially life-threatening toxidromes NMS and SS is as follows:

\section{Managing a case of suspected NMS}

The most important first step is to recognise the clinical features of this syndrome and stop further exposure to neuroleptics that block dopamine receptors. ${ }^{53}$ Supportive therapy such as intravenous rehydration in patients who are unwell, febrile and comatose and restoring electrolyte balance are the next steps. ${ }^{54}$ This may require admission to an intensive care unit. Medications with anticholinergic effects prevent sweating which may lead to further elevation of temperature and should be avoided. The specific treatment of NMS should be individualised based on the severity of the syndrome. Long-acting benzodiazepines such as lorazepam 1-2 mg administered intravenously or intramuscularly every 4-6 hours may be all that is required for mild cases of NMS. ${ }^{43}$ Traditionally dantrolene has been advocated for severe cases (table 8). Others have suggested the use of glutamate receptor antagonists such as amanta$\operatorname{dine}^{55}$ and intravenous levodopa ${ }^{56}$ to treat NMS. For patients with prominent catatonic features when other therapies have been ineffective, electroconvulsive therapy may be considered. ${ }^{57}$

\section{Managing a case of suspected SS}

The first step in the management of SS is to recognise the clinical signs and symptoms, and distinguish them from mimics, such as NMS. Discontinuation of all serotonergic agents is the next step, following which supportive care to control agitation, hyperthermia and autonomic dysfunction must be instituted. In mild cases, supportive care and administration of benzodiazepines (eg, diazepam $5 \mathrm{mg}$ intravenously), if the patient is 
Table 9 Treatment outlines for the common toxidromes in neurological practice

\begin{tabular}{|c|c|}
\hline Toxidrome & Treatment \\
\hline Adrenergic toxidrome & $\begin{array}{l}\text { Agitation may be treated with benzodiazepines, psychosis with haloperidol and hypertension with phentolamine, supraventricular } \\
\text { tachyarrhythmias with } \beta \text {-blockers. }{ }^{37}\end{array}$ \\
\hline Anticholinergic toxidrome & $\begin{array}{l}\text { Agitation can be treated with benzodiazepines, dexmedetomidine an } \alpha 2 \text {-adrenergic agonist approved by the US Food and Drug } \\
\text { Administration for the sedation of adults who are intubated on mechanical ventilation and in non-intubated adults who are undergoing } \\
\text { surgical procedures, has been used in adolescent cases. }{ }^{38} \text { If life-threatening such as cardiac arrhythmias occur, the cholinesterase } \\
\text { inhibitor physostigmine can reverse the abnormality. } \\
\text { Initial dose: } 0.5-2 \mathrm{mg} \text { intravenously (slow push) }{ }^{39}\end{array}$ \\
\hline Benzodiazepine toxidrome & $\begin{array}{l}\text { Flumazenil intravenous/intramuscular. } \\
\text { Initial dose: } 0.1-0.3 \mathrm{mg} \text { (bolus) intravenously*.40 }\end{array}$ \\
\hline Cholinergic toxidrome & $\begin{array}{l}\text { Atropine intravenously for any evidence of significant toxicity such as symptomatic bradycardia. } \\
\text { Initial dose: } 0.5 \mathrm{mg} \text { (bolus) intravenously* } 41\end{array}$ \\
\hline Drug-induced parkinsonism & Recognition and withdrawal of the offending drug. ${ }^{42}$ \\
\hline Neuroleptic malignant syndrome & $\begin{array}{l}\text { Cooling measures, rehydration, bromocriptine or other dopamine agonists orally (or via NG), consider dantrolene intravenously for severe } \\
\text { cases. } \\
\text { Initial doses: bromocriptine } 2.5-5 \mathrm{mg} \text { orally (or via NG) } 8 \text { hourly, dantrolene } 1-2.5 \mathrm{mg} / \mathrm{kg} \text { intravenously } 6 \text { hourly for } 48 \text { hours. }{ }^{43}\end{array}$ \\
\hline Parkinson hyperpyrexia syndrome & $\begin{array}{l}\text { Reinstitute treatment with levodopa or dopamine agonist orally (or via NG). }{ }^{44} \text { If due to suspected DBS battery failure, confirm by } \\
\text { interrogating device and get battery replaced. }{ }^{45}\end{array}$ \\
\hline Opioid toxidrome & $\begin{array}{l}\text { Naloxone intravenous/intramuscular/subcutaneous/intranasal. } \\
\text { Initial doses: } 0.2 \mathrm{mg} \text { (bolus) intravenously, } 0.4 \mathrm{mg} \text { intramuscular, } 0.8 \mathrm{mg} \text { subcutaneous; } 2 \mathrm{mg} \text { intranasal*..46 } 47\end{array}$ \\
\hline Serotonin syndrome & $\begin{array}{l}\text { Withdrawal of the offending agent and supportive care. Benzodiazepines may be used to treat agitation and tremor. Oral (or via NG } \\
\text { tube) cyproheptadine may be used as an antidote. } \\
\text { Initial dose: } 4-8 \mathrm{mg} \text { orally (or via NG). }{ }^{48} 49\end{array}$ \\
\hline $\begin{array}{l}\text { Tardive (antidopaminergic) } \\
\text { syndromes }\end{array}$ & $\begin{array}{l}\text { Early recognition and stopping the offending drugs is important as tardive syndromes can be highly resistant to drug treatment. Calcium } \\
\text { channel blockers, } \beta \text {-blockers, benzodiazepines have been tried but there is little evidence to support their use. }{ }^{50} \text { Tetrabenazine is effective } \\
\text { in some cases. }\end{array}$ \\
\hline $\begin{array}{l}\text { Tricyclic antidepressant } \\
\text { toxidrome }\end{array}$ & $\begin{array}{l}\text { Gastrointestinal decontamination. Activated charcoal ( } 1 \mathrm{gm} \text { orally or via NG) adsorbs TCAs. Intravenous fluids, cardiovascular and } \\
\text { respiratory support. Administration of sodium bicarbonate intravenously might be beneficial for patients with severe or life-threatening } \\
\text { TCA toxicity if there is a prehospital protocol for its use. }{ }^{52}\end{array}$ \\
\hline
\end{tabular}

${ }^{*}$ Repeat dosing may be required if response is inadequate or symptoms recur.

DBS, deep brain stimulation; NG, nasogastric tube; TCA, trcicyclic antidepressants.

agitated, may be adequate. ${ }^{58} 59$ In moderate and severe cases, administration of $5-\mathrm{HT}_{2 \mathrm{~A}}$ antagonists can be useful. $^{60}$ Cyproheptadine and chlorpromazine have been used but there are no clinical trials to support their use in such a scenario. Case reports of treatment with cyproheptadine have been reported with no major adverse effects ${ }^{49} 61$ and recovery can be within hours of cyproheptadine prescription when other therapies have failed. ${ }^{62}$

\section{CONCLUSION}

Prompt recognition and correct identification of toxidromes is vital in managing potential emergencies in neurology practice that can have high morbidity and mortality. Prevention can be a part of the approach to dealing with these problems and some toxidromes can be avoided by a combination of education and modifications to prescribing practices.

\section{Main messages}

- Movement disorder toxidromes can such as neuroleptic malignant syndrome (NMS) and serotonin syndrome (SS) can represent medical emergencies and a basic knowledge for recognising these conditions is essential for clinicians.

- Differentiating NMS from SS is important because treatments for these conditions, which can have some overlapping features, are different.

- Mortality and morbidity of some of these toxidromes can be high so instituting treatments, both generic and specific, in a timely manner is of paramount importance.

\section{Current research questions}

- The treatment for tardive movement disorder syndromes is suboptimal as recovery from these conditions can be delayed for months and years, and almost always never complete. Research into underlying molecular mechanisms and better treatments would be invaluable for patients.

- There is a lot of variation in the phenotypical manifestations and severity of patients developing movement disorder toxidromes even when exposed to similar doses of medications. The mechanisms for this heterogeneity remain largely unexplained.

- Preventive treatments are largely non-existent at present for most toxidromes apart from avoiding the exposure to the culprit drug but some of these drugs have important therapeutic value for treating the conditions that they are indicated and licensed for. Finding molecules and drugs that can prevent the development of certain toxidromes that can be anticipated when prescribing a particular class of drugs to patients would be useful.

Contributors Both authors contributed equally to the paper.

Competing interests None declared.

Provenance and peer review Not commissioned; externally peer reviewed.

\section{REFERENCES}

1 Jones JD, Mogali S, Comer SD. Polydrug abuse: a review of opioid and benzodiazepine combination use. Drug Alcohol Depend 2012;125:8-18.

2 Griffin CE III, Kaye AM, Bueno FR, et al. Benzodiazepine pharmacology and central nervous system-mediated effects. Ochsner J 2013;13:214-23. 
3 Wilson ME, Lee GK, Chandra A, et al. Central anticholinergic syndrome following dobutamine-atropine stress echocardiography. Echocardiography 2011;28: E205-6.

4 Takahashi M, Ubukata $S$, Sato $E$, et al. [Acute respiratory failure associated with cholinergic crisis: report of five cases and review of the literature]. Nihon Kokyuki Gakkai Zasshi 2011:49:877-84.

5 Aquina CT, Marques-Baptista A, Bridgeman P, et al. OxyContin abuse and overdose. Postgrad Med 2009;121:163-7.

6 Sternbach H. The serotonin syndrome. Am J Psychiatry 1991;148:705-13.

7 Crome P. Poisoning due to tricyclic antidepressant overdosage. Clinical presentation and treatment. Med Toxicol 1986;1:261-85.

8 Doshay LJ, Constable K, Zier A. Five year follow-up of artane treatment; the outcomes in 461 Parkinson cases. Trans Am Neurol Assoc 1953:3(78th Meeting):173-5; discussion, 75-7.

9 Yahr MD, Duvoisin RC, Schear MJ, et al. Treatment of parkinsonism with levodopa. Arch Neurol 1969;21:343-54.

10 Katzenschlager R, Sampaio C, Costa J, et al. Anticholinergics for symptomatic management of Parkinson's disease. Cochrane Database Syst Rev 2003(2): CD003735.

11 Lang AE. High dose anticholinergic therapy in adult dystonia. The Canadian journal of neurological sciences. Le journal canadien des sciences neurologiques 1986;13:42-6.

12 Jabbari B, Scherokman B, Gunderson $\mathrm{CH}$, et al. Treatment of movement disorders with trihexyphenidyl. Mov Disord 1989;4:202-12.

13 Liou LM, Shih PY. Successful treatment of rubral tremor by high-dose trihexyphenidyl: a case report. Kaohsiung J Med Sci 2006;22:149-53.

14 Kastrup 0, Eikmeier G, Gastpar M. [Central anticholinergic intoxication syndrome. A contribution to the differential diagnosis of exogenous psychoses]. Dtsch Med Wochenschr 1991;116:1748-51.

15 Hendrickson RG, Morocco AP, Greenberg MI. Pilocarpine toxicity and the treatment of xerostomia. J Emerg Med 2004;26:429-32.

16 Mena MA, de Yebenes JG. Drug-induced parkinsonism. Expert Opin Drug Saf 2006:5:759-71.

17 Sokoro AA, Zivot J, Ariano RE. Neuroleptic malignant syndrome versus serotonin syndrome: the search for a diagnostic tool. Ann Pharmacother 2011;45: e50

18 Gurrera RJ, Caroff SN, Cohen A, et al. An international consensus study of neuroleptic malignant syndrome diagnostic criteria using the Delphi method. J Clin Psychiatry 2011;72:1222-8.

19 Kontaxakis VP, Vaidakis NM, Christodoulou GN, et al. Neuroleptic-induced catatonia or a mild form of neuroleptic malignant syndrome? Neuropsychobiology 1990;23:38-40.

20 Woodbury MM, Woodbury MA. Neuroleptic-induced catatonia as a stage in the progression toward neuroleptic malignant syndrome. J Am Acad Child Adolesc Psychiatry 1992;31:1161-4.

21 Keyser DL, Rodnitzky RL. Neuroleptic malignant syndrome in Parkinson's disease after withdrawal or alteration of dopaminergic therapy. Arch Intern Med 1991:151:794-6.

22 Sechi GP, Tanda F, Mutani R. Fatal hyperpyrexia after withdrawal of levodopa. Neurology 1984;34:249-51.

23 Reutens DC, Harrison WB, Goldswain PR. Neuroleptic malignant syndrome complicating levodopa withdrawal. Med J Aust 1991;155:53-4.

24 Gibb WR, Griffith DN. Levodopa withdrawal syndrome identical to neuroleptic malignant syndrome. Postgrad Med J 1986;62:59-60.

25 Cheung YF, Hui CH, Chan JH. Parkinsonism-hyperpyrexia syndrome due to abrupt withdrawal of amantadine. Hong Kong Med J 2011;17:167-8.

26 Konagaya M, Goto Y, Matsuoka Y, et al. Neuroleptic malignant syndrome-like condition in multiple system atrophy. J Neurol Neurosurg Psychiatr 1997;63:120-1.

27 Oates JA, Sjoerdsma A. Neurologic effects of tryptophan in patients receiving a monoamine oxidase inhibitor. Neurology 1960;10:1076-8.

28 Boyer EW, Shannon M. The serotonin syndrome. N Engl J Med 2005;352:1112-20.

29 Twardowschy CA, Bertolucci CB, Gracia Cde M. Pontine and extrapontine osmotic myelinolysis after the syndrome of inappropriate secretion of antidiuretic hormone (SIADH) associated with fluoxetine: case report. Arquivos de neuro-psiquiatria 2007;65(3B):858-64

30 McAllen KJ, Schwartz DR. Adverse drug reactions resulting in hyperthermia in the intensive care unit. Crit Care Med 2010;38(6 Suppl):S244-52.

31 Sun-Edelstein C, Tepper SJ, Shapiro RE. Drug-induced serotonin syndrome: a review. Expert Opin Drug Saf 2008;7:587-96.

32 Dunkley EJ, Isbister GK, Sibbritt D, et al. The Hunter Serotonin Toxicity Criteria: simple and accurate diagnostic decision rules for serotonin toxicity. Qjm 2003;96:635-42.
33 Schneider SA, Udani V, Sankhla CS, et al. Recurrent acute dystonic reaction and oculogyric crisis despite withdrawal of dopamine receptor blocking drugs. Mov Disord 2009;24:1226-9.

34 Gregory RP, Smith PT, Rudge P. Tardive dyskinesia presenting as severe dysphagia. I Neurol Neurosurg Psychiatr 1992;55:1203-4.

35 Yassa R, Lal S. Respiratory irregularity and tardive dyskinesia. A prevalence study. Acta Psychiatr Scand 1986;73:506-10.

36 Thim T, Krarup NH, Grove EL, et al. Initial assessment and treatment with the Airway, Breathing, Circulation, Disability, Exposure (ABCDE) approach. Int J Gen Med 2012;5:117-21.

37 Richards JR, Albertson TE, Derlet RW, et al. Treatment of toxicity from amphetamines, related derivatives, and analogues: a systematic clinical review. Drug Alcohol Depend. 2015;150:1-13.

38 Gee SW, Lin A, Tobias JD. Dexmedetomidine infusion to control agitation due to anticholinergic toxidromes in adolescents, a case series. J Pediatr Pharmacol Ther 2015;20:329-34

39 Stellpflug SJ, Cole JB, Isaacson BA, et al. Massive atropine eye drop ingestion treated with high-dose physostigmine to avoid intubation. West J Emerg Med 2012:13:77-9.

40 Weinbroum AA, Flaishon $R$, Sorkine $P$, et al. A risk-benefit assessment of flumazenil in the management of benzodiazepine overdose. Drug Saf 1997:17:181-96.

41 Leikin JB, Thomas RG, Walter FG, et al. A review of nerve agent exposure for the critical care physician. Crit Care Med 2002;30:2346-54

42 Bondon-Guitton E, Perez-Lloret S, Bagheri H, et al. Drug-induced parkinsonism: a review of 17 years' experience in a regional pharmacovigilance center in France. Mov Disord 2011;26:2226-31.

43 Strawn JR, Keck PE Jr, Caroff SN. Neuroleptic malignant syndrome. Am J Psychiatry 2007:164:870-6.

$44 \mathrm{Kim} J \mathrm{H}$, Kwon TH, Koh SB, et al. Parkinsonism-hyperpyrexia syndrome after deep brain stimulation surgery: case report. Neurosurgery 2010;66:E1029.

45 Urasaki E, Fukudome T, Hirose M, et al. Neuroleptic malignant syndrome (parkinsonism-hyperpyrexia syndrome) after deep brain stimulation of the subthalamic nucleus. J Clin Neurosci 2013:20:740-1.

46 Clarke SF, Dargan PI, Jones AL. Naloxone in opioid poisoning: walking the tightrope. Emerg Med J 2005;22:612-16.

47 Doe-Simkins M, Walley AY, Epstein A, et al. Saved by the nose: bystander-administered intranasal naloxone hydrochloride for opioid overdose. Am J Public Health 2009;99:788-91.

48 Ables AZ, Nagubilli R. Prevention, recognition, and management of serotonin syndrome. Am Fam Physician 2010;81:1139-42.

49 Graudins A, Stearman A, Chan B. Treatment of the serotonin syndrome with cyproheptadine. J Emerg Med 1998;16:615-19.

50 Egan MF, Apud J, Wyatt RJ. Treatment of tardive dyskinesia. Schizophr Bull 1997:23:583-609.

51 Jankovic J. Drug-induced and other orofacial-cervical dyskinesias. Ann Intern Med 1981:94:788-93.

52 Woolf AD, Erdman AR, Nelson LS, et al. Tricyclic antidepressant poisoning: an evidence-based consensus guideline for out-of-hospital management. Clin Toxicol (Phila) 2007;45:203-33.

53 Reulbach U, Dutsch C, Biermann T, et al. Managing an effective treatment for neuroleptic malignant syndrome. Crit Care 2007;11:R4.

54 Sechi G, Manca S, Deiana GA, et al. Acute hyponatremia and neuroleptic malignant syndrome in Parkinson's disease. Prog Neuropsychopharmacol Biol Psychiatry 1996;20:533-42.

55 Kornhuber J, Weller M, Riederer P. Glutamate receptor antagonists for neuroleptic malignant syndrome and akinetic hyperthermic parkinsonian crisis. J Neural Transm Park Dis Dement Sect 1993;6:63-72.

56 Nisijima K, Noguti M, Ishiguro T. Intravenous injection of levodopa is more effective than dantrolene as therapy for neuroleptic malignant syndrome. Biol Psychiatry. United States 1997:913-14.

57 Caroff SN, Mann SC, Keck PE Jr, et al. Residual catatonic state following neuroleptic malignant syndrome. J Clin Psychopharmacol 2000;20:257-9.

58 Fisher AA, Davis MW. Serotonin syndrome caused by selective serotonin reuptake-inhibitors-metoclopramide interaction. Ann Pharmacother 2002:36:67-71.

59 Lappin RI, Auchincloss EL. Treatment of the serotonin syndrome with cyproheptadine. N Engl J Med 1994;331:1021-2.

60 Gillman PK. The serotonin syndrome and its treatment. J Psychopharmacol (Oxford) 1999:13:100-9.

61 Gillman PK. Successful treatment of serotonin syndrome with chlorpromazine. Med J Aust 1996;165:345-6.

62 Stevenson E, Schembri F, Green DM, et al. Serotonin syndrome associated with clozapine withdrawal. JAMA Neuro/ 2013:70:1054-5. 